腹腔内進展と腹膜播種をきたした浸潤性胸腺腫の 1 例

市立豊中病院外科

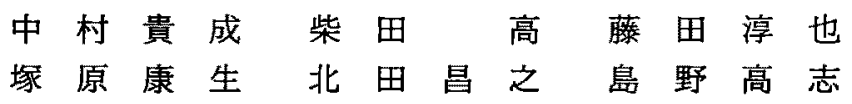

症例は59歳, 女性. 左上腹部腫㿔と食欲不振を主訴に当院受診. 既往歴として48歳時 に左胸水に対し他院入院加療. 腹部 CT 検㚗では左上腹部に小児頭大の不整形な充実性 腫癔が認められ, 全身麻酔下に開腹したところ左横隔膜下・胃前面に小児頭大・表面不 整・易出血性・淡黄白色の腫湯が認められた。腫瘍は左横隔膜に強固に浸潤し多数の腹 膜播種を伴い, 術中迅速病理診断で胸腺腫と判明したため, 腫浧および腹膜播種を可及 的に摘出するに留めた. 術後胸部X線を再検討したところ左上縋隔に腫瘍像が認められ た. 胸部 CT 検査で前縦隔に横隔膜へと続く腫瘍像が認められ, 浸潤性胸腺腫が横隔膜 へ直接浸潤し腹腔内進展・腹膜播種したものと考えられた. 化学療法を行い残存腫瘍は 縮小㑯向にあり, 術後 9 力月生存中である.

索引用語：浸潤性胸腺腫, 腹䑤内浸潤, 腹膜播種

\section{はじめに}

胸腺腫は前縦隔に発生する腫場であり，病理学的に は胸腺から発生した上皮性腫富と定義されている。し たがって横隔膜浸潤をきたしても腹腔内へ進展し腹部 腫溜として触知されることは極めて稀であると考えら れる。

今回われわれは，腹腔内進展と腹膜播種をきたした 浸潤性胸腺腫の 1 例を経験したので若干の文献的考察 を加え報告する。

患者：59歳, 女性.

$$
\text { 症例 }
$$

主訴：左上腹部腫瘤, 食欲不振.

家族歴：特記すべき事なし.

既往歴：48歳 左胸水貯留し他院入院加療（肺結核 といわれたらしいが詳細不明). 50歳から高血圧・糖尿 病に対し当院で加療中.

現病歴：2002年 6 月頃から左上腹部腫瘤に気づき前 医受診. 腹部 CT 検査にて左。上腹部に巨大な腫敀像が 認められ当科紹介受診.

入院時現症：身長 $152 \mathrm{~cm}$, 体重 $45 \mathrm{~kg}$ 。体温 $36.5^{\circ} \mathrm{C}$,

2002 年12月20日受付 2003 年 4 月21日採用

〈所属施設住所〉

于560-8565 曹中市柴原町 4-14-1
血圧 $148 / 80 \mathrm{mmHg}$, 脈拍 72 回 $/$ 分. 左上腹部に径 $20 \mathrm{~cm}$ の弾性硬の腫瘤を触知したが，王痛や通過障害は認め られなかった。また重症筋無力症の徵候も認められな かった.

入院時検査所見 : 血算は正常であったが, 生化学検 查において AST 81IU/1, LDH 547IU/1, ALP 372IU/ 1, CK 235IU/1 と高値を認めた. 腫瘍マーカーは正常で あった(表 1)。また抗アセチルコリン受容体抗体は陰 性であった。

胸部 X 線写真：左肺の容積減少を認めるも肺野の $\mathrm{X}$ 線透過性は良好で coin lesion も認められなかった。

\section{表 1 入院時検查所見}

\begin{tabular}{|c|c|c|c|c|}
\hline WBC & $5,600 \quad / \mu l$ & AST & 81 & $\mathrm{IU} / 1$ \\
\hline $\mathrm{RBC}$ & 451 万 $/ \mu 1$ & ALT & 21 & $\mathrm{IU} / \mathrm{I}$ \\
\hline $\mathrm{Hb}$ & $12.0 \mathrm{~g} / \mathrm{dl}$ & LDH & 547 & $\mathrm{IU} / 1$ \\
\hline $\mathrm{Ht}$ & 38.5 & ALP & 372 & $\mathrm{IU} / \mathrm{I}$ \\
\hline \multirow[t]{2}{*}{ Plt } & 28.1 万 $/ \mu !$ & $\mathrm{CK}$ & 235 & $\mathrm{IU} / \mathrm{l}$ \\
\hline & & $\mathrm{TP}$ & 7.4 & $\mathrm{~g} / \mathrm{dl}$ \\
\hline CEA & $1.9 \mathrm{ng} / \mathrm{ml}$ & Alb & 4.1 & $\mathrm{~g} / \mathrm{dl}$ \\
\hline CA19-9 & $6 \mathrm{U} / \mathrm{ml}$ & T-bil & 0.56 & $\mathrm{mg} / \mathrm{dl}$ \\
\hline \multirow[t]{4}{*}{$\mathrm{SCC}$} & $1.0 \mathrm{ng} / \mathrm{ml}$ & AMY & 100 & $\mathrm{IU} / 1$ \\
\hline & & BUN & 21 & $\mathrm{mg} / \mathrm{dl}$ \\
\hline & & $\mathrm{Cr}$ & 0.6 & $\mathrm{mg} / \mathrm{dl}$ \\
\hline & & $\mathrm{CRP}$ & 0.21 & $\mathrm{mg} / \mathrm{dl}$ \\
\hline
\end{tabular}




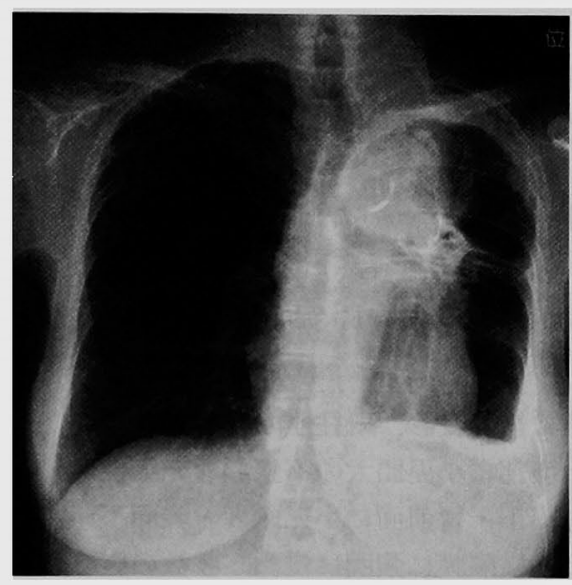

図 1 胸部レントゲン写真：綐隔はやや左 方に偏移するも明らかな腫痬像は認めら れなかった。

緥隔は左方に偏移しゃや拡大していたが， 2 年前の写 真と比較してもほとんど変化は認められなかった。左 胸水貯留の既往歴もあり，肺結核による陳旧性変化と 考えた (図 1 ).

腹部 CT 検査 : 左上腹部に小児頭大の不整形な充実 性腫瘍が認められた。造影効果は不均一であり, 腫瘍 により胃・膵・脾臓は圧排されていた。また肝臓や腹 膜に腫瘤像は認められなかった（図 2 ).

上部消化管内視鏡検查：胃体中部前壁に壁外性圧迫 像が認められたが, 粘膜病変は認められなかった。

注腸造影検査：横行結腸と下行結腸が尾側へ偏移し ていたが，粘膜病変は認められなかった。

腹部血管造影検査：腫瘍は血管豊富であり，栄養動 脈は左胃動脈・左肝動脈・脾動脈からの分枝と考元ら 机(図 3 ).

以上の結果から巨大胃粘膜下腫場や後腹膜腫瘍を疑 い，全身麻酔下に開腹手術を施行した。

手術所見：開腹すると左横隔膜下・胃前面に小児頭 大・表面不整・易出血性・淡黄白色の腫㕫が認められ た. 腫湟は血管豊富であり胃体中部大彎・肝左葉下面・ 脾蔵・後腹膜と接していたが比較的容易に剥離可能で あった。しかし左横隔膜に強固に浸潤しており，横隔 膜原発腫瘍あるいは胸腔内腫瘍の横隔膜浸潤が疑われ た。また腹水はなかったが腹部全体に数 $\mathrm{cm}$ 大の腹膜 播種が多数認められた。術中迅速病理診断の結果が胸 腺腫であったため，腫毫および腹膜播種を可及的に摘 出するに留めた。手術時間は 2 時間23分, 出血量は
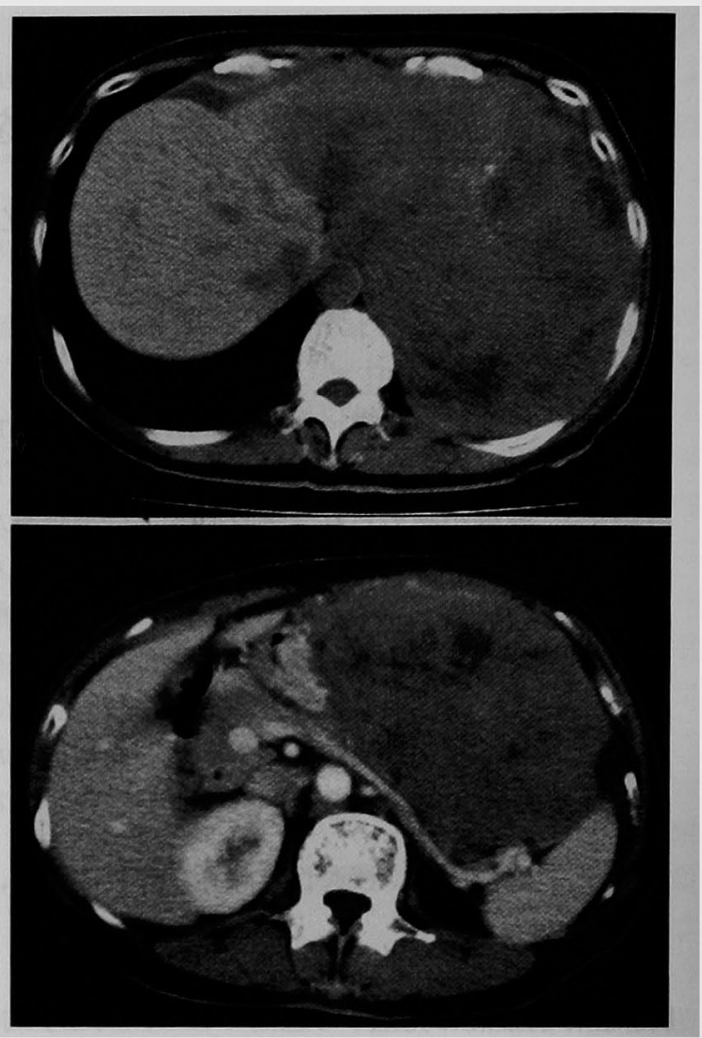

図 2 腹部 CT 検查：左上腹部に小児頭大の不整形 な充実性腫漡が認められた。造影効果は不均一で あり，腫瘍により胃・脺・脾臓は圧排されていた。

笚純

\section{2,100ml であつた。}

病理組織学的診断：腫場の大きさは $18 \times 15 \times 8$ $\mathrm{cm}$, 重量は $1,160 \mathrm{~g}$ であった. 可及的に摘出した腹膜播 種の重量は計 $400 \mathrm{~g}$ に及んだ. 病理組織学的に腫湯は核 異型性の乏しい上皮性細胞とリンパ球で構成され，胸 腺腫（混合型）と診断された（図4).

術後経過：術後胸部X線写真を再検討したところ上 縦隔左側の腫瘤影を見落としていたことに気づき，胸 部 CT 検查を施行したところ左肺尖から胸部大動脈周 囲・前縦隔を経て横隔膜へと続く腫崵像が認められ, 浸潤性胸腺腫の横隔膜浸潤と矛盾しない所見であっ た.また肺内に転移巣は認められなかった，術後合併 症なく経過し, 内科で化学療法 (ADM + CDDP) 施行 し残存腫煌は縮小傾向にあり, 術後 9 力月現在生存中 である。なお，既往歴について再度本人や家族に問診 し前医にも問い合わせたが，11年も前のことであり病 


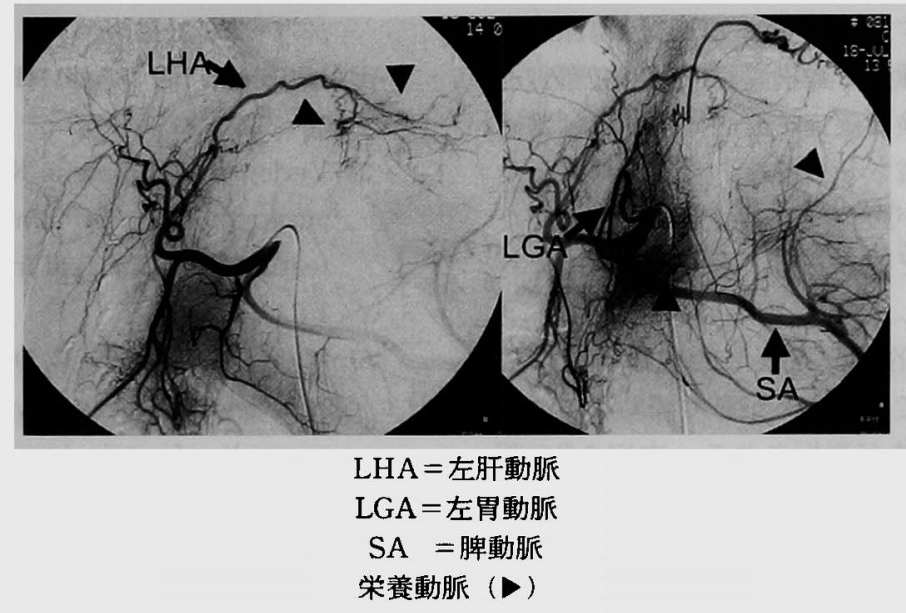

図 3 腹部血管造影検査：腫覅は血管豊富であり, 栄養動脈は左胃動 脈・左肝動脈・脾動脈からの分枝と考えられた.

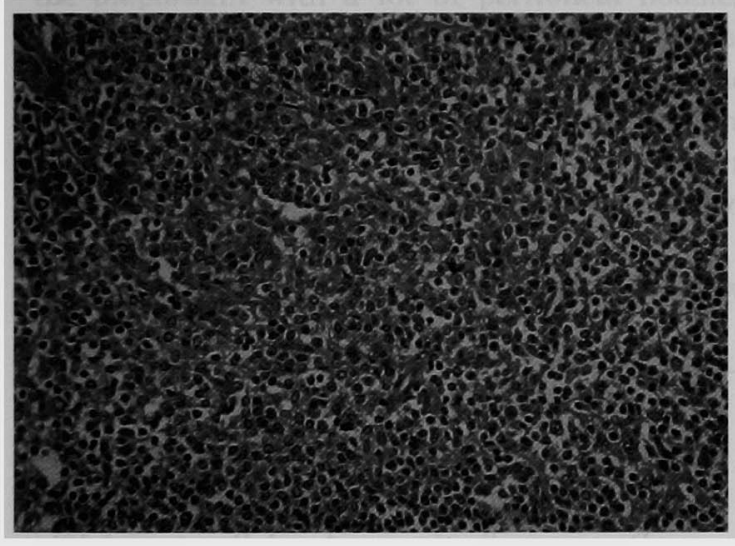

図 4 病理組織学的検査：腫瘍は核異型性の乏しい上皮 性細胞とリンパ球で構成され，胸腺腫 (混合型) と診断 された（HE 染色 $\times 400 ）$.

名や治療内容など詳細は不明であった。

\section{考察}

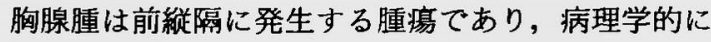
は胸腺から発生した上皮性腫瘍と定義されている11.

向田ら ${ }^{2)}$ 報告によると15-84歳 (平均49.7歳)に発 生し, 男女比は0.94：1である。

臨床病期分類には正岡分類 ${ }^{3}$ が広く用いられ，III期， IV期を浸潤性胸腺腫とする報告が多い2). 浸潤性胸腺 腫は発育が遅く局所進展性は強いが胸腔内に留まるこ とが多く，しばしば重症筋無力症や赤芽球ろうなどを 合併することを特徵とする゙3.

病理組織型についてはリンパ球優位型, 混合型, 上
皮細胞優位型に分類するのが一般的であるが，上皮細 胞優位型に浸潤傾向が強く予後不良であるとの報告が 多(22)3.

胸腺腫の浸潤性は細胞形態や組織構築などの病理組 織学的所見よりも手術時または摘出標本検索時におけ る被膜外浸潤や胸膜播種の有無により判定され，生物 学的悪性度も組織学的所見よりも肉眼的浸潤度と相関 すると報告されている(14). 自験例も病理組織学的には 核異型はほとんどなく悪性所見にそしかった。

胸腺腫の胸腔外あるいは遠隔転移の割合は, 1.8-4 \%と報告され ${ }^{516)}$, 転移部位は肝・骨・リンパ節が多い7).

腫瘍の胸腔外進展経路として横隔膜脚後腔（いわゆ る大動脈裂孔）は後腹膜腔と胸部後絣隔の連絡通路て あり緹隔腫瘍の進展経路となりうることは従来から報 告があるが8), 胸腺腫が後腹膜進展をきたす報告は少 ない ${ }^{9100}$ ．また横隔膜前方内の欠損部(その傍正中部は いわゆる Morgagni 孔）は胸膜外腔と前腹壁の腹膜外 腔の連絡通路となるため同様に縦隔の腫瘍性病变の進 展経路となりうるとの報告もある11)。

しかし自験例において腹部腫場は胃・膵・肝や後腹 膜に接していたが剥離は容易であり，むしろ左横隔膜 そのものに強固に浸潤し多数の腹膜播種が認められた ことを特徵とする。また胸部 CT 検查でも横隔膜脚行 腔の腫瘍像は明らかでなく, 血行性転移やリンパ行性 転移よりも横隔膜浸潤をきたした腫瘍が直接腹腔内へ 進展し発育し腹膜播種をきたした可能性が高いと考え られた。

今回, 腹部腫湟の術前診断で開腹手術を施行したが, 
胸部 X線写真を再検討すると上縦隔左側に腫場像が認 められ，術前から䋛隔腫場も鑑別診断にいれて精查加 療すべきであり，針生検で確定診断を得ていれば手術 も回避できたと樑く反省させられた。しかし検索した 限りでは浸潤性胸腺腫が腹腔内に直接進展・発育した 報告は清水ら ${ }^{12)} 1$ 例だけであり, 極めて珍しい発育 形式と考え敢えて報告した.

浸潤性胸腺腫の基本的治療は根治的切除術である が, 完全切除が不可能であることが多く補助療法とし て放射線療法や化学療法が選択される，向田ら゙の報 告によると, IVa 期およびIVb 期の10年生存率はそれ ぞれ7.2\%，0\%であり，極めて予後不良である。

したがって自験例のように横隔膜に浸闘, 腹腔内に 進展し腹部腫瘤を形成した場合, 無症状であれば腹部 腫瘤に対して針生検を施行し確定診断を得た後に放射 線療法や化学療法を施行し, 圧迫による通過障害など の症状が出現すれば可及的に切除し街後補助療法を施 行すへきであると考えられた。

\section{結語}

左上腹部腫瘤を主訴とした浸潤性胸腺腫の 1 例を経 験した. 手術所見から絸隔の胸腺腫が横隔膜に浸潤し 腹腔内に進展, 腹膜播種を形成したと考えられた。

なお, 本論文の要旨は第172回近䪵外科学会 $(2002$ 年11月, 神戸市)で報告した。

\section{文献}

1) Rosai J, Levine GD:Tumors of the thymus. Atlas of tumor pathology. Fascicle 13, Armed Forces Institute of Pathology, Washington DC, 1976, p34-151

2）向田尊洋, 市場晋吾, 青江 基他：胸腺蕾128例の 臨床病理学的検討. 日胸臨 $56: 497-501,1997$

3) 正岡 昭: 呼吸器外科学. 南山堂, 東京, 1987, p277-288

4) LeGolvan DP, Abell MR : Thymomas. Cancer 39 : 2142-2157, 1977

5) Verley JM, Hollmann KH : Thymoma, A comparative study of clinical stages, histologic features, and survival in 200 cases. Cancer 55 : 1074-1086, 1985

6) Maggi G, Giaccone G, Donadio M : Thymomas, A review of 169 cases, with particular reference to results of surgical treatment. Cancer 58: 465 $-776,1986$

7) Ichino $V$, Obuchi $M$, Suko $K$, et al : Malignant thymoma with distant metastases: A case report and review of the literature. Jpn J Clin Oncol $13: 733-740,1983$

8) Borlaza GS, Kuhns LR, Seigel RS, et al : The Posterior Pararenal Space; An Escape Route for Retrocrural Masses. J Comput Assist Tomogr $3: 470-473,1979$

9）西村哲夫，金子昌生，大場 覚他：後腹膜進展を 呈した浸潤性胸腺腫の 1 例. 画像診断 $7: 1284$ $-1287,1987$

10）大河原清, 古瀨 信, 水谷好秀他：熹性胸腺腫， 悪性胸膜中皮腫の横隔膜脚後腔を介した後腹膜腔 進展. 踟放線 40:55一61，1995

11) Kleinman PK, Brill PW, Whalen JP: Anterior Pathway for Transdiaphragmatic Extension of Pneumomediastinum. Am J Roentgenol 131: 271-275, 1978

12）清水義友, 岡野匡雄, 鉿木高咗他：異常な広がり を認めた悪性胸腺腫の一剖検例。日大医誌 51 ： 315-319, 1992 


\title{
A CASE OF INVASIVE THYMOMA DEVELOPING INTO INTRA-ABDOMINAL MASS WITH PERITONEAL METASTASIS
}

\author{
Takaaki NAKAMURA, Takashi SHIBATA, Jyunya FUJITA, \\ Yasuo TSUKAHARA, Masashi KITADA and Takashi SHIMANO \\ Department of Surgery, Toyonaka Municipal Hospital
}

Thymomas are slow growing tumor and their extrathoracic progression or metastases are rare.

We report a case of invasive thymoma developig into intra-abdominal mass with peritoneal metastasis.

A 59-year-old woman complained of left upper abdominal mass and appetite loss. There were previous histories of left pleural effusion eleven years before. She was admitted to our hospital because abdominal CT study revealed intra-abdominal huge mass.

With a suspicion of retroperitoneal tumor or huge gastrointestinal stromal tumor, the patient was operated on.

The tumor was contiguous to anterior to the stomach and the pancreas and proved to be arising from the diaphragm with a lot of peritoneal nodules. Intraoperative pathological examination detected thymoma, and we performed incomplete resection.

We reviewed chest $\mathrm{X}$-ray again and found the tumor shadow in upper mediastinum. Chest CT study after operation showed mediastinal tumor continuing on the diaphragm.

Histpathologically, the tumor consisted of lymphocytes and epithelial cells without mitosis and was diagnosed as the mixed invasive thymoma developing into abdominal cavity with peritoneal metastasis over the diaphragm from the mediastinum.

Adjuvant chemotherapy was started and it was effective. She has been followed at present as of 9 months after operation. 